ISSN: 1838-3815 (online) Journal Homepage: https://ojs.deakin.edu.au/index.php/itlge/

\title{
Students as colleagues: The impact of working on campus on students and their attitudes towards the university experience
}

Luke Millard ${ }^{1}$

Corresponding author: Luke Millard (luke.millard@bcu.ac.uk)

${ }^{1}$ Birmingham City University, http://orcid.org/0000-0002-9426-674

\begin{abstract}
This paper considers research that engaged with a university wide population of students who were employed on campus to better understand why they chose to work alongside their studies; how this impacted upon their attitudes to study and the university, and the benefits for those students. This paper reveals that the primary motivation to work on campus is the development of skills; considers the nature of those skills and behaviours; discovers the changing relationship between student workers and university staff; and discusses how engagement leads to an enhanced sense of student confidence and belonging. The paper concludes by considering the implications for the university and sector and how the outcomes might be best deployed for impact on those students who would most benefit.
\end{abstract}

Keywords: students, employability, confidence, skills, belonging, colleague, relationships

\section{Introduction}

Over $70 \%$ of the undergraduate student population at Birmingham City University (BCU) engage with paid work opportunities alongside their studies (UK Engagement Survey 2017). For some students this employment equates to a full time job that enables them to finance their lives and their ability to study (NUS 2012). As a University, the implications are far reaching as it challenges the notion of the full-time student devoted to their discipline, and also how a university might best adapt to this situation, to engage with and support that student. This research considered one element of that picture, and one possible solution, through a population of students who were employed on campus by the University. This research explores the reasons why students choose to work on campus alongside their studies, how this impacted upon their attitudes to study and their relationship with the University, and what benefits they drew from the experience.

\section{Developing the jobs on campus approach}

The need for students to find work alongside their studies was partially driven by the UK Government policy when it introduced the white paper Putting Students at the Heart of the System (DBIS, 2011). This reinforced the market-led approach to higher education in the UK, which began in 1998, with the introduction of student payment of tuition fees. As these fees increased over time and additional governmental financial support has been withdrawn, there has been a move in the UK for students to seek employment to support their studies and the needs of their student lives (NUS 2012, NASES and NUS 2012). The outcome sees payment of the tuition fee deferred until after 
the student completes their degree, but the additional removal of bursaries for the majority of academic programs has had the additional impact of meaning students need to pay for accommodation and lifestyle expenses from their own or parental resources. The Pound in your Pocket (NUS 2012) states many students are struggling to make ends meet, concentrate on their studies and stay the course, because financial support is systematically inadequate across both further and higher education. The research detailed in this paper sought to reveal whether this financial hardship is a key driver for students seeking employment alongside their studies or whether additional drivers took priority.

The concept of students paying substantial tuition has been well established in the USA. One of the responses of universities there has been to create student employment opportunities within the university so that students can work on campus to support their studies financially within an educationally supportive environment. Investigations across the sector as to whether anything like this approach had been explored in UK higher education revealed that the Higher Education Funding Council for England (HEFCE) had undertaken exploratory work around the topic (Sullivan, 2008) and had produced a report based on work with universities in the USA. One of the universities highlighted in the HEFCE report was Northwest Missouri State University (NWMSU). A visit to NWMSU by BCU staff had a significant impact on those involved as it showed what could be possible. The situation in Missouri was very different to that of BCU but the ambition and commitment shone through and was something to which a university could aspire. NWMSU saw the need to create jobs so that students could afford to study and live at the University, but also recognised the value of engaging students through employment and how this could enhance the nature of the University and its sense of community.

Whilst there is a history of students working alongside their studies on university campuses in the USA and elsewhere, as evidenced by Perna (2010) and Wang et al. (2010), this was a relatively new phenomenon in the UK and therefore there was limited research. In particular, the UK higher education system has very little history of strategically funded, institution wide campus student employment services. American Universities, such as NWMSU, had identified the multi-layered benefits of such programs for both the student and the university. As Sullivan (2008) states students and staff were clear that an experience of the world of work before graduation helped make students more employable. He also reported that:

A point repeated many times by students in interview was, mostly, they believed that working as well as studying helps make them better students. This was a surprising finding. Students explained that they managed their time better because they had to. Students believed they had a better experience and led fuller lives than students who did not work (p.9).

HEFCE saw the potential of student employment in 2008, but little had developed in the UK at that time with the exception of job shops on campus which mainly supported external employment opportunities (NASES, 2012). At the time of starting this research, the strategic engagement of students in on campus employment had only been adopted by a very small number of UK universities, but this number is now growing. It would appear that the UK higher education sector has started to recognise that through student employment on campus, universities can have a profound impact on student employability and development, not to mention the benefits to the University itself.

\section{Drivers for students seeking employment}

The move to students working significant numbers of hours alongside their studies in the UK was predictable as the model of higher student fees had existed in the USA for many years. Perna (2010), stated that work is a fundamental part of life for many undergraduate students (p. i). Her collaborative research (Perna, Cooper, \& Li, 2007) revealed that $75 \%$ of dependent undergraduates and $80 \%$ of independent undergraduates in the USA worked whilst they studied. Within Europe the

Millard, L. (2020). Students as colleagues: The impact of working on campus on students and their attitudes towards the university experience. Journal of Teaching and Learning for Graduate Employability, 11(1), 37-49. 
situation is slightly different and varies between countries. Simón, Díaz and Castejón (2017) report evidence drawn from 23 countries that around 60\% to 70\% of students work in Anglo-Saxon and Nordic countries and between $20 \%$ and $30 \%$ work in Southern Europe (p.285).

Not only do students work, but in some places they work significant hours. Perna et al. (2007) report that in the USA, the dependent graduate works an average of 24 hours per week, whilst independent undergraduates work virtually full time jobs with 34.5 hours. Perna (2010) saw employment and working alongside your studies as being the norm for US students. She also challenged those institutions that that did not recognise this shift as failing to recognise that higher education is generally not the primary life environment of working students (2010,p. i). This continues to offer a fundamental challenge for the higher education sector in the US and UK as it seeks to reconcile the historical perspective of a full-time student against the increasing demands placed upon their time by society and the needs to support their education and their student lifestyle.

One of the challenges for developing on campus employment opportunities is the potential for it to have a detrimental impact on student studies. Astin (1993) found that working off campus could be negatively associated with completing an undergraduate degree, but that working on campus was positively associated with student retention and completion of studies. Riggert et al., (2006) confirmed this and identified that the effects of on-campus employment were characterised as positive in nature (p.69) through students having less distance to travel to work, being able to study around their work, and through students having more flexibility around when they can work by working for a more understanding employer.

Factors that impact on why a student may choose to work on campus can be determined by extrinsic and/or intrinsic motivations. The motivations for students working on campus are likely to vary between individuals from the financial (Simón et al., 2017) to the development of employability skills to a more altruistic engagement. The relationship between extrinsic and intrinsic motivations is contested in the literature as there are suggestions that extrinsic motivations destroy the intrinsic. However, Kember (2016) notes that there is still no consensus as to whether extrinsic motivations undermines intrinsic (p. 25). There is a suggestion that some extrinsic motivations, such as wanting to gain an excellent job on completion of a university career, could be seen as being complementary and co-existing alongside more 'noble' intrinsic motivations around interest in the subject. For example, Lewis (2010) suggests that on-campus employment is one type of college experience that can promote engagement and goes further to suggest that employment may provide an opportunity for a student to engage with certain learning domains more frequently (p.156) and therefore enhance skills development in those areas whilst receiving payment.

\section{The intervention}

In February 2012, the University applied to the Higher Education Academy's Change Academy program to develop an initiative that would create a student employment service on campus. The focus was to create an employment service that put students at the heart of the University through placing them in job roles across all aspects of the University's provision. Through this action the University hoped to build a greater sense of community between staff and students. The belief was that such an opportunity could improve student satisfaction and success, impact on the sense of learning community through new staff/student relationships, and help students gain a better, graduate level job.

The idea originated through the University's work in student engagement that saw students work alongside academic staff on pedagogically related initiatives (Freeman, Millard, Brand, \& Chapman 2014; Millard \& Hargreaves, 2015; Curran \& Millard, 2016). In 2010 the Student Academic Partners (SAP) initiative was awarded the Times Higher Education award for Outstanding Support for Students and in 2013 the collaborative nature of this student engagement work was recognised when the University and Students' Union won the first Higher Education Academy (HEA) and

Millard, L. (2020). Students as colleagues: The impact of working on campus on students and their attitudes towards the university experience. Journal of Teaching and Learning for Graduate Employability, 11(1), 37-49. 
National Union of Students institutional partnership award. These awards recognised the sector leading partnership work, between staff and students, which sought to improve the quality of the student learning experience.

These partnership activities were embedded within the SAP program that was, originally, run collaboratively with the Students' Union, and supported up to 40 projects each year. This saw the employment of around 200 students each year in SAP projects. Evaluation around the SAP program provided data that suggested that students were gaining wider benefits from these activities than was initially planned (Nygaard, Brand, Bartholomew, \& Millard, 2013). Through the evaluation process, students identified changing relationships with staff and the creation of a greater sense of learning community, but discussions with students and staff also revealed that additional learning experiences were taking place that were more focused around skills development and employability learning. The creation of employability focused learning experiences had not been a principle behind the rationale for the creation of SAP, but it was rapidly developing as a key strength of the program. Students and staff reported consistently on the project management, communication and leadership skills that were being developed through the student roles in which they engaged.

\section{Methodology}

The research took a case study approach and, after having gained ethics approval from the University, engaged with the University's 'Jobs on Campus' program. This is a distinct, institutional program and the investigation focused on a time period from March 2015 to May 2016. The program employed around 800 students in that year and the quantitative survey targeted the 384 students who were employed at the date of the survey point.

The survey received responses from 153, a $40 \%$ response rate. The students were drawn from all faculties across the university and were studying in a wide range of undergraduate degree programs. The jobs in which students were employed varied from mentoring and co-creator roles in SAP, to administrative assistants, technicians, demonstrators, library shelvers, event assistants, junior researchers and marketing support posts. The survey requested significant student demographic detail before asking the pertinent questions around their views to working on campus. The questions asked are detailed below.

Student Survey questions:

- On average, how many hours of paid work do you undertake per week at the University?

- Do you have additional paid employment outside of the university? If so how many hours do you work on average per week?

- What is the postcode or area for the place you work at outside of the university? (e.g. B42 2SU or Perry Barr)

- What type of paid work do you undertake outside of the University?

- Do you also undertake any voluntary or caring work? If so how many hours per week on average?

- On average, how many hours per week of study do you undertake at the University (classroom, library, study groups etc on campus)?

- On average, how many hours per week of study do you undertake away from the University campus?

- Where do you learn and/or study most effectively?

- What is your primary motive for working on campus at BCU? 
- As a result of working on campus, I believe that:

- I have a better relationship with staff than if I were only a student

- I work harder at my academic studies

- I am more likely to ask questions of my lecturers

- I am more understanding of the university (if things are not perfect on my course)

- I am more motivated to succeed at the university

- I feel like I belong more at the University than if I were just a student

- I am more satisfied with my university experience

- My time management skills have improved

- I am better at prioritising my work

- I am better organised

- I spend more time studying on campus

- My confidence has grown

- I have talked to my university work colleagues about my academic studies and gained support or advice from them

- I am unable to participate in other university activities (clubs) that I feel that I would like to

- I feel isolated from other students on my course

- I have less time to study

- I think it will have a negative impact on my academic results

The research followed a mixed methods approach that consisted of a quantitative survey of students employed on campus that then informed the running of three qualitative focus groups with a total of 14 students. Cresswell (2009) identified that the situation today is less quantitative versus qualitative and more how research practices lie somewhere on a continuum between the two (p. 4). For this research the focus groups enabled attitudes and behaviours to be studied and allowed a variety of views to evolve that could be further stimulated by the shared experience. Participants were recruited by an email call for volunteers across the student population that had been surveyed previously. This resulted in 14 volunteers stepping forward. The participants self-selected into three groups on the basis of their availability, rather than any particular personal characteristics or their subject of study. Kamberelis and Dimitriadis (2011) suggest the reason for the use of this research technique when they state that focus groups afford researchers access to social-interactional dynamics that produce particular memories, positions, ideologies, practices and desires among specific groups of people (p.559).

The focus groups took a maximum of two hours and saw students asked a set of questions that further explored the outcomes of the survey. These are detailed below:

Identity: What were your reasons for taking a job at the University? Please list in priority order.

Skills: What skills did you develop whilst working at the university?

Behaviours: How did working at the university impact on your academic studies and why?

Community: How did your relationship with staff alter as a result of you working on campus?

Attitude: When working at the University, how did your attitude towards the University change?

What is the best aspect of working as a student on campus? Would you take unpaid work at the University? 
Each student recorded their individual response to each question on an answer sheet and was then asked to debate their view with the other students in the group to identify a common position. This summary position was also recorded by one of the students on a new sheet that allowed the researcher to collect individual and group perspectives.

\section{Results}

\section{Student characteristics}

The survey sought to identify the demographic characteristics of the students who featured in the survey to see if any information could be identified as to why a student might work on campus. Two thirds of students who completed this survey were female and the ethnicity spread between white British students and non-white almost exactly mimicked the University population where, in 2016/17, internal university data revealed that 45 per cent of students were recorded as being from the black and minority ethnic population. This is reassuring for a university that seeks to be inclusive and enable all student groupings to be able to access jobs on campus.

The majority of surveyed working students on campus were between the ages of 20-24. This would seem appropriate, as new, younger students are likely to settle into university life in their first year and become more aware of opportunities once they know how the university operates. The biggest single group of students who completed this survey were in their second year $(45 \%)$ with the remainder split equally between first and final year students. This reflects something about the jobs offered as many university managers recruiting students target second years as they have an awareness about the institution whilst not being weighed down with concerns about preparing for their assessments in their final year.

The work of Astin (1993, p. 196) that identified a negative impact of working away from campus on student academic performance was a key prompt as the jobs on campus service was developed. Therefore, participants in the survey were asked about whether they undertook any paid employment in addition to their University campus work as this may influence perspectives. Of the 153 students who took part in this survey, $83(54 \%)$ also worked off-campus. These individuals were asked on average how many hours they work per week. In total, 63 responded. Students reported that they worked hours in additional jobs that ranged from one to 20 hours per week. One of the reasons for creating the OpportUNIty program was to enable students to gain sufficient paid employment opportunities on campus so that they need not work away from the University. It would appear that the University was unable to offer sufficient employment opportunities to prevent this exodus from campus. However, it could also be that students seek a variety of working experiences to support their development.

Students were asked, on average, how many hours paid work they undertook per week at the University. Results shows that between one and 10 hours of paid work is most commonly undertaken by OpportUNIty students on campus, accounting for $75 \%$ of the students working on campus. Only $15 \%$ of students worked for a period of time of between 16-20 hours. Due to program timetables and other commitments, limited working hours would be expected. It also supports the earlier identified need for students to find work off campus, as there may have been insufficient hours of work available on campus.

\section{Student motivations}

When asked about their primary motive for working on campus at Birmingham City University $54 \%$ of students answered that the key reason was to develop skills to help them get a job. This showed that a large number of students undertaking work experience opportunities were principally taking their futures into consideration as they strove to grasp experiences that may make them more employable. Astin (1993, p. 235) recognises this desire within his research that showed a significant positive correlation in self-reported job related skills through students who held a part-time job on

Millard, L. (2020). Students as colleagues: The impact of working on campus on students and their attitudes towards the university experience. Journal of Teaching and Learning for Graduate Employability, 11(1), 37-49. 
campus. The second most popular motive behind employment on campus was to earn money as $31 \%$ of students identified this reason whilst a further $14.4 \%$ stated they wanted to give something back to the University.

When this subject was taken to the focus group interviews the outcomes revealed that a combination of these factors was often at play as students made the decision to work on campus or not. At an individual response level, feedback revealed that comments were consistent and followed three paths that focused upon financial survival, flexibility and skills development. This can be embodied in the response from one student who stated that:

...to be able to leave the external job (Supermarket), be able to buy essential things (food), be able to work with other students and staff and have a positive impact.

A key strength of the jobs on campus program would appear to be its ability to fit around a student's study program. Comments recorded across individual responses included:

Work fits easily around study hour.

University working hours are flexible.

Flexibility.

One student offered a prioritisation order that revealed a multiplicity of reasons for taking a job on campus:

1. Money 2. Flexibility 3. Personal Development 4. CV opportunity/employability.

This was echoed in another who explained that $s / h e$ wanted to:

...enhance my employability and $\mathrm{CV}$, to earn money, to meet new people and work with others outside the university.

The comments from students at the focus groups exhibited a combination of extrinsic and intrinsic motivations, but with an emphasis on the extrinsic.

\section{Impact on student behaviours}

The research asked students about their typical study hours and the impact campus employment has had on their study habits since working at the University. When asked about campus employment in relation to their studies just $24 \%$ felt they had less time to study whilst over $65 \%$ of students felt that their typical study hours had not been affected. The remaining $11 \%$ were unsure. This question suggests that whilst campus work enables development of practical experience, it also allows students to retain focus on their course of study during these periods of employment. It also supports another outcome where $55 \%$ of students stated they spent more time studying on campus as a result of working there.

The creators of the jobs on campus program wanted it to generate a positive impact on the student learning experience and students' attitudes towards studying. This was viewed as an important indicator of the benefit for students of working on campus. $64 \%$ of students in the research felt that they worked harder at their academic studies because they worked on campus. Alongside their studies, students were asked if campus employment had affected their ability to take part in other university activities. This revealed similar results as almost $80 \%$ either disagreed or strongly disagreed with the statement 'I am unable to participate in other University activities that I would like to'. This indicated that students believe that they are able to balance effectively a range of activities (clubs, studies, and employment) during their time at BCU.

When asked if students felt isolated from their peers as a result of campus employment, over $90 \%$ either disagreed or strongly disagreed. It is important that students are always connected with fellow students during their studies, not just from an educational perspective but also a social perspective. These answers suggest that despite undertaking campus employment (and possibly

Millard, L. (2020). Students as colleagues: The impact of working on campus on students and their attitudes towards the university experience. Journal of Teaching and Learning for Graduate Employability, 11(1), 37-49. 
additional activities), students are still engaging with their peers effectively. This is vital as the success of a jobs on campus program requires students to feel that they remain integrated within the university community and their course cohort (Furr \& Elling, 2000) to enable that sense of belonging (Thomas, 2012) to mature and embed within the student perception.

Finally, students were asked if they felt campus employment would have a negative impact on their academic results. $91 \%$ of students felt that campus employment would not have a negative impact on their academic results whilst less than $5 \%$ thought it would. Timberlake and Frank (2006) talk of student employment at university enabling students to bring together academic work and real world problem solving (p.137) and leading to a strengthening of peer to peer relationships. These outcomes would suggest that when undertaking employment with the University, students are able to study successfully and participate in the university community whilst retaining a strong connection with their peers.

\section{Student development and attitudes to the University}

The research showed that since undertaking part-time employment at the University over $85 \%$ of students felt their relationship with university faculty and staff had improved. In the focus groups, the issue of the relationship with staff at the University provoked a great deal of feedback. The need for universities to develop more effective relationships between students and staff is becoming increasingly important as external metrics, through tools such as the UK National Student Survey, seek to measure the nature of the relationship. Through the focus groups, students offered insights into how their relationships with staff had changed, making the following comments:

Staff see me on the same level. I get access to staff rooms which means I can go to my tutors and speak to them.

...relationship with staff greatly improved while working.

...better, stronger relationships. I started to understand staff workload.

I became more connected to staff and as a result I have been able to work on further projects with staff, creating more professional relationships.

I became closer to members of staff and treated them more like friends and colleagues rather than just staff members.

These comments suggest that a higher level of personal and community connections was being made through this new means of engagement.

One of the strongest indicators from the survey was that since undertaking employment on campus almost $90 \%$ of students felt a greater sense of belonging towards Birmingham University, with over $55 \%$ selecting 'Strongly Agree'. In the focus groups, students spoke of the development of pride and engagement with the University as evident in these comments:

...the university became more a personal thing, something I represented, rather than something I attended.

...my attitude towards the university has become more friendly and healthy through coordination during work and on projects.

...l became aware of more issues in and around my course, student projects and the wider university.

Student employees were asked to assess perceptions of their own development as a result of working for the University. The four areas evaluated were time management, organisation, confidence and the ability to prioritise workloads (see Figure 1). Students had identified that the need to gain employability skills was one of the main reasons for taking a job on campus, and therefore the identification of their perceived skills development was important. 
$78 \%$ agreed that their time management skills had developed since working for the University, of which $31 \%$ strongly agreed. Similar results were also displayed when analysing the development of workload prioritisation (77\%) and organisation skills (80\%). These comparable scores could be a result of the integrated nature of the relationship between the three skills sets and suggests a level of consistency across student scoring.

The survey also revealed that over $53 \%$ of students strongly agreed their confidence had grown; the largest of any development. Another $35.9 \%$ 'agreed' with this, meaning almost $90 \%$ of students supported this statement. The students in the focus groups also highlighted a key learning piece around developing confidence including some quite specific comments from students around 'being able to give a speech to an audience' and 'I am not intimidated standing in front and speaking to large crowds' and 'voicing opinions in a professional environment'.

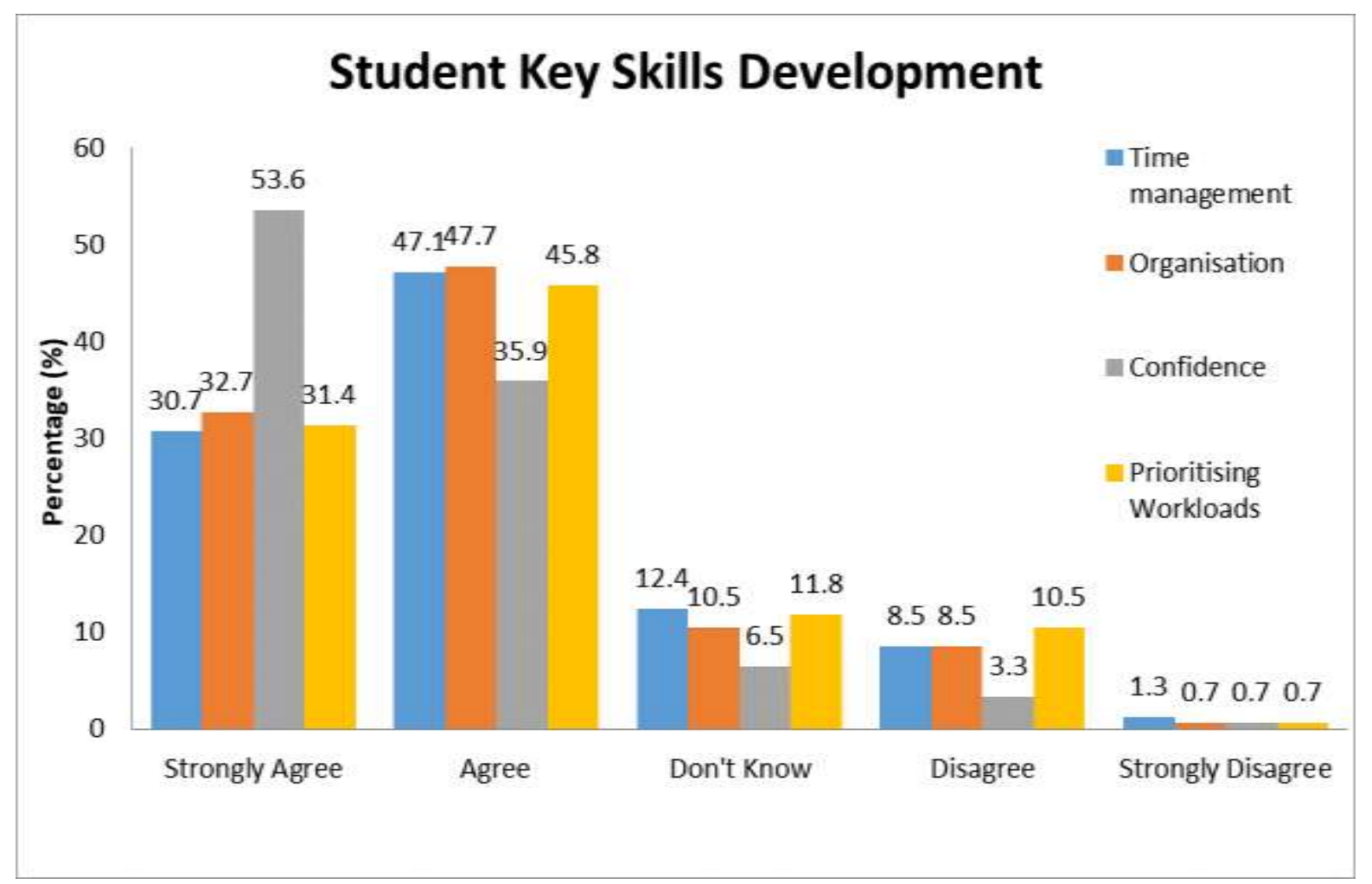

Figure 1: Student Key Skills Development

\section{Analysis}

The analysis section replicates the previous results component to enable reflection on the outcomes and draw in supporting literature.

\section{Student characteristics}

The survey data suggested that students who worked on campus were more likely to be living on campus in student accommodation and would not be commuter students. The three highest scoring areas of residence have significant university or privately owned halls of residence for student accommodation. Students who move to the city and do not have the local job connections, that may be part of the commuter students' employment history, could be more likely to be interested in a university provision as they are unlikely to have those local connections with employers. This could have significant implications for a university that was seeking to engage more diversely with its local communities or conversely, and was seeking to attract students from a national or 
international context. However, whilst this research can generalise, to an extent, it is clear that individual decisions and circumstances will always mean that the factors that influence a student's decisions will be personal to that individual student as they consider the myriad of relationships and circumstances that would lead to generating such a decision.

This outcome echoes the findings of the National Union of Students' report (Thomas \& Jones, 2017) that highlights the split lives of commuter students who have a life, job and social networks within their own community and visit the university purely to engage in educational experiences. Those students do not wish to mix their home and university lives and this could see a reluctance from those commuter students to engage with work on campus as this function has already been addressed in their local community through a job that may have started well before the student joined the university.

The survey revealed that the combination of on campus, off campus employment and potential volunteering/caring duties was different for each individual student and required them to have the ability to manage these commitments so that they did not adversely impact their academic studies. The question that should be considered and may concern universities is which of these take primacy in the student mind. Would a student be content to work significant hours and be able to afford to study and live at university and as a result see their academic award at a lower level? The decision making process of the individual student will determine that answer.

\section{Student motivations, behaviours and development}

Student responses for why they chose to be employed on campus resonated with the suggestion of Kember (2016) and Biggs (1987) that extrinsic drivers were likely to take precedence in the student mind. It is likely that for many students the need to survive financially is the primary driver for undertaking any form of work alongside their academic studies. However, once this extrinsic need for finance to enable students to continue to learn has been achieved, other drivers can be considered by students and can form components of how students identify and rationalise the benefits of working on campus.

Students spoke of developing a new relationship with colleagues and the university. Roberts and Styron's (2010) asserted that an enhanced relationship with staff would help create a greater sense of connectedness between student and the institution could be a significant benefit of employing students within a university for many reasons ranging from retention of students and student success through to the influence that they may have over others students on their program of study. Students hinted at a move from professional recognition and acceptance to genuine collegiality and even the development of friendships as the boundaries between staff and student started to blur. The breaking down or blurring of boundaries through this employment opportunity could be seen as a benefit for those universities seeking to create a greater sense of community between students and staff and enhance membership of the University (McMillan \& Chavis, 1986).

This is an important outcome as Thomas (2012) points to universities needing to generate in students a strong sense of belonging to ensure retention and student success and this sense would appear to be enhanced strongly through working on campus. Astin (1993) stated that his research indicated that having an on campus job would tend to bring the student into contact with a wider variety of fellow students and staff (P. 230), which supports the development of a sense of being part of something more than just attendance at a place and has been reflected in the findings from students. This is supported by the results around enhanced student academic effort that relates to the work of Zhao and Kuh (2004) who identified increased academic effort being evident in students who feel part of a community at university and who have generated those relationships.

The results around student key skills development were encouraging for anyone seeking to enhance student development practices. Timberlake and Frank (2006) identified core skills that students develop through working alongside academic study, highlighting that, depending on the job role fulfilled, students gain many transferable skills including planning, organising, problem solving, co-

Millard, L. (2020). Students as colleagues: The impact of working on campus on students and their attitudes towards the university experience. Journal of Teaching and Learning for Graduate Employability, 11(1), 37-49. 
ordinating, public speaking, working with others, communicating orally and in writing and coping with frustrations (p. 143). This would reflect the evidence provided by Dallam and Hoyt (1981) that highlighted the impact on student time management practice through working and echoes the insights of Sullivan (2008) from the HEFCE visit to US Universities. The impact of such skills development could be impactful on a student's academic success as well as their professional behaviours.

The strong increase in student confidence levels represents an important result for students as generating self-belief (Zepke \& Leach, 2010) is a crucial development for students seeking to grow and develop. As students develop and learn more about themselves through working on campus they develop a stronger sense of self leading to clarity and stability, and a feeling of warmth for this core self as capable, familiar and worthwhile as highlighted by Chickering and Reisser (1993, p. 50). This level of comfort would certainly support a sense of student belonging within an institution. Timberlake and Frank (2006) echoed this view when they identified that students achieve confidence, communication skills and connections as some of their biggest gains (p.143) when they work alongside their degree.

It might be argued that for students attending a newer university and seeking to compete with students from more established 'research focused' universities in the job market, this is a crucial development that provides them with the belief and self-effficacy to show the talent they have developed when competing with students from other places for jobs. This is echoed in the work of Chickering \& Reisser (1993) who highlighted 'a key developmental step for students is learning to function with relative self-sufficiency, to take responsibility for pursuing self-chosen goals, and to be less bound by the opinion of others (p.47). That creation of inherent self-confidence is a significant output of the jobs on campus experience and one of which the sector should be cognisant.

\section{Conclusion}

This research suggests that when students choose to work on campus, they do so for a variety of reasons. The type of student who accesses such roles is likely to be a campus-based student who does not have existing employment ties within the area. This would appear to have some logic as commuter students could already have a long standing and worthwhile job. However, this does offer some challenges for universities as they seek to engage with their entire student population. In addition, the findings reveal that students strongly believe that working on campus will not hinder their academic development and that they are able to still engage with their peers and the other social activities of an engaging university life.

These findings are heartening and challenging for universities as they consider the impact of such a program on campus employment. Perna (2010) asked universities to consider ways to transform employment into an experience that can enhance students' intellectual development (p.33). She felt that the combination of economic and personal pressure on students means that universities should reconceptualise the working experience to offer more benefit to students' educational outcomes. The opportunity to utilise student jobs on campus as part of student placement/work experience activity should be addressed by universities as it could better integrate the experience within the intellectual and academic development of students.

For all universities, the finding that $90 \%$ of students in the survey agreed that their confidence had grown as a result of working on campus is important. The focus groups reinforced this outcome with students talking of not being intimidated when speaking to large groups and of developing the ability to voice their opinion in a professional manner. Cook-Sather et al. (2014) confirm this finding as they reported that students who in engage in partnership activities exhibit enhanced confidence, motivation and enthusiasm and deepened understanding of, and contribution, to the academic community (p.100). Perhaps the development of confidence and the desire to work harder at their studies is also related to the fact that three quarters of students talk to their new work colleagues about their studies. Students identified that the 'relationship with staff greatly improved while

Millard, L. (2020). Students as colleagues: The impact of working on campus on students and their attitudes towards the university experience. Journal of Teaching and Learning for Graduate Employability, 11(1), 37-49. 
working'. These conversations may have been brief or in depth, but the opportunity for a mentoring relationship to develop through shared understandings is a welcome outcome for this area of work. This could also have the further benefit as identified by Jarvis, Dickerson and Stockwell (2014, p. 220) of helping students learn skills and techniques around how they might learn and enhance educational outcomes.

In addition, the way in which working on campus impacted on students' attitudes towards the University is significant for universities seeking to develop such an offer. The generation of a greater sense of connectedness or membership was explained by McMillan and Chavis (1986) who stated membership is the feeling of belonging or sharing a sense of personal relatedness. Aligned with this membership was a sense of mattering, of making a difference to the group and of the group mattering to its members (p.4). The new relationships that student colleagues make with university faculty and staff can often be seen through a mentoring lens and an enhanced sense of membership and belonging can be generated for those students who need it most.

This may be even more important for the more economically deprived parts of the student population. In the UK, and as the NUS (2012) report suggests: Excessive working hours are associated with poor wellbeing and with origination in areas with low higher education participation rates (p.4). Studies in Spain (Simón et al., 2017) have found that a significant portion of those who work are motivated by necessity, especially to help family finances (p. 291) and over half the students reported that it would not be possible to study without such an income. For universities, such as BCU, the impact could be great as the widening participation focus of the University attracts a significant proportion of students who could ascribe to come from economically deprived backgrounds. This creates a challenge for universities, but also, perhaps, an opportunity through a student jobs on campus focus to better integrate these particular students into the fabric of the university, build confidence and belonging, and thus enable academic and professional success.

\section{References}

Astin, A. W. (1993). What matters in college? Four critical years revisited. San Francisco: Jossey-Bass.

Biggs, J. (1987). Student approaches to learning and studying. Melbourne: Australian Council for Educational Research.

Chickering, A.W., \& Reisser, L. (1993). Education and identity (2 ${ }^{\text {nd }}$ ed). San Francisco: Jossey Bass.

Cook-Sather, A., Bovill, C., \& Felten, P. (2014). Engaging students as partners in learning and teaching: A guide for faculty. San Francisco, CA: Jossey-Bass.

Cresswell. J. W. (2009) Research design: Qualitative, quantitative, and mixed methods approaches. London: Sage Publications.

Curran, R., \& Millard, L. (2015). A partnership approach to developing student capacity to engage and staff capacity to be engaging: Opportunities for academic developers. International Journal for Academic Development, 21(1), 67-78

Dallam, J.W., \& Hoyt, D.P. (1981). Do students have enough time to study? College and University 57(1), 84-91.

Department of Business, Innovation and Skills (BIS) (2011). Putting students as the heart of the system. London: The Stationery Office Limited.

Freeman, R., Millard, L., Brand, S., \& Chapman, P. (2014). Student academic partners: Student employment for collaborative learning and teaching development. Innovations in Education and Teaching International, 51(3), 233-243.

Furr, S.R., \& Elling T.W. (2000). The influence of work on college student development. NASPA Journal, 37(2), 454-470.

Jarvis, J., Dickerson, C., \& Stockwell, L. (2013). Staff-student partnership in practice in higher education: The impact on learning and teaching. Procedia-Social and Behavioral Sciences, 90, 220-25.

Kamberelis, G., \& Dimitriadis, G. (2011) Focus groups: contingent articulations of pedagogy, politics and inquiry. In N.K. Denzin \& S. Lincoln (Eds), The Sage handbook of qualitative research (pp.545-562), $4^{\text {th }}$ Ed. London: Sage.

Kember, D. (2016). Understanding the nature of motivation and motivating students through teaching and learning in higher education. Singapore: Springer.

Millard, L. (2020). Students as colleagues: The impact of working on campus on students and their attitudes towards the university experience. Journal of Teaching and Learning for Graduate Employability, 11(1), 37-49. 
Lewis, J. (2010). Job fare: Workplace experiences that help students learn. In L.W. Perna (Ed.), Understanding the working college student: New research and its implications for policy and practice (pp.155-176). Virginia, USA: Stylish Publishing.

McMillan, D.W., \& Chavis, D.M. (1986). Sense of community: A definition and theory. Journal of Community Psychology, 14(1), 6-23.

Millard, L., \& Hargreaves, J. (2015). Creatively employing funding to support innovation. Innovations in Education and Teaching International, 52(3), 335-334.

NASES/NUS (2013). Students working while studying London, UK: NUS

NUS (2012). The pound in your pocket. Accessed from: https://www.nus.org.uk/PageFiles/12238/PIYP Summary Report.pdf (last accessed 11 July 2017)

Nygaard, C., Brand, S., Bartholomew, P., \& Millard, L. (2013). Student engagement: Identity, motivation and community. Oxfordshire: Libri Publishing.

Perna, L. (2010). Understanding the working college student - new research and its implications for policy and practice. Virginia, USA: Stylus publishing.

Perna, L., Copper, M., \& Li, C. (2007). Improving educational opportunities for students who work. Readings on Equal Education, 22, 109-160.

Riggert, S. C., Boyle, M., Petrosko, J. M., Ash, D., \& Rude-Parkins, C. (2006). Student employment and higher education: Empiricism and contradiction. Review of Educational Research, 76(1), 63-92.

Roberts. J., \& Styron. R. (2010). Student satisfaction and persistence: Factors vital to student retention. Research in Higher Education Journal, 6(3), 1-18.

Simón, H., Diaz, J. M., \& Castejón, J-L. (2017). Analysis of university student employment and its impact on academic performance. Electronic Journal of Research in Educational Psychology, 15(2), 281-306.

Sullivan, P. (2008). Report of the HEFCE Leadership, Governance and Management Fund supported project LGMF 101 Managing a substantial increase in on-campus student employment. A forthcoming challenge for HR management and leadership. HEFCE. Bristol. Available at: file://C:/Users/Study/AppData/Local/Temp/LGMF\%20101\%20report\%2011.pdf

Thomas, L. (2012). Building student engagement and belonging in higher education at a time of change: Final report from the What Works? Student Retention and Success Program. UK: Higher Education Academy.

Thomas, L., \& Jones, R. (2016). Student engagement in the context of commuter students. London: The Student Engagement Partnership.

Timberlake, B., \& Frank, S. (2006). Marquette University: The student coordinator model. In E. Zlotkowski, N.V. Longo \& J. Williams, J. (Eds.) Students as colleagues: Expanding the circle of service-learning leadership (pp.135-146). Providence, USA: Campus Compact, Brown University.

UK Engagement Survey (2017). Advance HE. https://www.advance-he.ac.uk/knowledge-hub/ukes-2017report (last accessed 12.5.20)

Wang, H., Kong, M., Shan, W., \& Vong, S.K. (2010). The effects of doing part-time jobs on college student academic performance and social life in a Chinese society. Journal of Education and Work, 23(1), 79-94.

Zepke, N., \& Leach, L. (2010). Improving student engagement: Ten proposals for action. Active Learning in Higher Education, 11(3) p 167-177.

Zhao, C.M., \& Kuh, G. (2004). Adding value: Learning communities and student engagement. Research in Higher Education, 45(2), 115-138.

Zlotkowski, E., Longo, N.V., \& Williams, J. (Eds) (2006). Students as colleagues: Expanding the circle of servicelearning leadership. Providence, USA: Campus Compact, Brown University. 